\title{
CAT'S BRAIN AND CRYPTOGRAPHY: TWO NOTES ON MEDIEVAL RECIPES FROM THE MS BNF NAL 693*
}

\section{С. В. Иванов. Мозг кошки и криптография: две заметки о средне- вековых рецептах в рукописи BNF NAL 693}

В статье рассматриваются два рецепта из англо-нормандской рукописи, содержащей коллекцию технических и медицинских рецептов. В первом предлагается интересный метод лечения заболевания, вызванного приемом мозга кошки, с помощью вареных сов. Во втором, дающем описание смеси, используемой для удаления букв с пергамента, наблюдается любопытный пример криптографии. Рецепты рассматриваются в контексте сведений и рекомендаций сходного типа с целью выявить отличия, которые могут указывать на местную традицию. Оба рецепта были добавлены в рукопись владельцем, который был, вероятнее всего, практикующим врачом, и поэтому важны для понимания народных технических и медицинских знаний в Британии 14-ого века.

Ключевые слова: средневековая медицина, рецепты, рукописная традиция, криптография.

Technical and medical recipes are often found side by side in the medieval manuscripts as they transmit practical knowledge very much demanded by practising physicians, astrologers, scribes and illuminators. These collections of notes have been sometimes added to the manuscripts by their later possessors who used the blank leaves and space as their private note-book. It is always interesting to see how the notes interact with and supplement the main texts which as a rule belong to the learned and well-established tradition. The manuscript Bibliothèque nationale de France, nouvelles acquisitions latines 693 is a classic example of such a multifunctional use as it combines the Latin and Anglo-Norman treatises which constitute the main text with a large amount of later additions made perhaps by several hands. The manuscript was most probably written in the last quarter of the 13th century (perhaps some parts of it even earlier), while the additions were being made up to the

\footnotetext{
* Работа выполнена при поддержке гранта РНФ 17-18-01624. Автор выражает благодарность С.Д. Клейнер за полезное обсуждение.
} 
middle of the 14 th century ${ }^{1}$. In this paper, I will consider two such additional recipes - one medical and one technical - which provide some interesting details as to the lower stratum of medical learning and the use of cryptography.

\section{1.}

Toxicology has long had its lawful place within medicine (see Touwaide 1994). It was a well-established discipline within medieval medical learning because poisons, their effects and treatment were a subject necessarily covered in any compendium and examined in many special treatises ${ }^{2}$. It had its own theoretical problems centered around the proper definition of poison and how it acts $^{3}$. However, vitally important were the practical instructions as to which poison caused what symptoms and how they should be cured. Thus, the greater part of the treatises consisted of such lists which differed considerably from the modern ones and included many substances that seem exotic and in any case non-venomous to the modern reader.

During the Middle Ages and well into the modern period, the cat's brain was regarded as extremely poisonous. As for the cat itself, the opinions varied. Some medieval physicians considered it a very morbiferous animal ${ }^{4}$. Avenzoar (Ibn Zuhr, d. 1162) in his

${ }_{1}^{1}$ On the MS, see Ivanov, Falileyev 2017, with bibliography.

${ }^{2}$ On medieval toxicology and treatises see the seminal work by Lynn Thorndike (HMES 1934: III, 526-545); see also Gibbs 2017.

${ }^{3}$ See Chandelier 2009. The explanation based on the humoral theory was supplemented by the notion of the "specific form" which gained popularity due to Avicenna, and this twofold scheme persisted till Christophorus de Honestis who viewed the specific form as the only way in which the poison operated. This theoretical discussion seems to have little, if any, impact on the subject of this paper since all the authors touching on the theoretical issues do not go beyond humoral explanations, see Sante Arduino and Eustachio Rudio below.

${ }^{4}$ We do not consider here of course such cases as rabidity or bites which seem to have been clearly distinguished from the effects of the poisonous nature of the cat or its brain. Andrea Bacci (d. 1600), the personal physician (archiater) of the Pope, discussing the danger of cat rabies cites a curious, allegedly "very old" inscription in the Basilica of Santa Maria del Popolo in Rome:

Hospes, disce nouum mortis genus, improba feles,

Dum trahitur, digitum mordet, et intereo.

'Stranger, learn a new kind of death: a vile cat

Bites on the finger while being dragged out, and now I am dying'.

(See Bacci 1586: 16.) 
"Liber Theysir" known in the West in Latin translation by John of Capua from the year 1280 (Nicoud 2007: 133) stated that inhaling cat's breath weakens the humidity of the lungs and of the whole body (Avenzoar 1490, Prohemium Ivb). Maimonides (d. 1204) whose dietetic treatise "De regimine sanitatis" was translated into Latin by the same John of Capua at the very end of the 13th or in the very beginning of the 14 cent. and then once more by an anonymous translator (Nicoud 2007: 161-2; Bar-Sela, Hoff, Faris 1964: 11, Ackermann 1986: 54-55) held that the vestments made from cat hide cause illness, as cats' odour and breath do. Therefore it is recommended to stay away from them and from the odour of their breath (Maimonides 1518: Tractatus Quartus, fol. d, cf. translation by Bar-Sela, Hoff, Faris 1964: 31).

This attitude, however, was not peculiar to the Arab medicine, as can be seen from the "Physica" of Hildegard of Bingen written between 1150 and 1160, that is, long before these translations were made. She asserts that the cat has a natural communion with the frog and the serpent since in the summer-time when the heat is great, it licks frogs and serpents to survive and therefore it becomes internally poisonous so that its brain and flesh are poisonous. During this time, the cat's heat is harmful and venomous for a man, but at other times it is harmless for a healthy man. But if a man is infirm in the head or paralytic in any other member, then he should not wear a cap of cat's skin. But he who tastes some of cat meat, will turn mad, and his flesh will usually turn venomous therefrom (Physica VII, 26 $=$ Hildegrad von Bingen 2010: 353-354).

Abraham Zacuto Lusitano describes some cases of lethal cat rabies, adding that one should not have them as pets because they are not only subject to rabies, but also may be venomous in general, see Zacuto 1637: 495. It should be also mentioned here that a distinction is very often difficult to draw between poison and sorcery, but the learned treatises which we are preoccupied with do not refer to any magical use of cat's brain, regarding it as a pure "medical" substance, although they were obviously closely associated in the popular mind; on the subject see Collard 2003, esp. 28, 53, and 56. The essence and effect of the substance, however, remained obscure even in the scientific literature and it was related to the occult sphere through the concept of the "specific form", see ibid., 44-45. On medical views on the cat see Bobis 2000: 92-96 and Bobis 1997. A summary of the opinions of various authors on the cat, cat's brain and their morbiferous qualities see already by Conrad Gessner 1620: 321-322 in his Historiae animalium first issued in 1551. 
A considerable time later, Pietro Andrea Mattioli (d. 1577), the Habsburgs' personal physician, claimed that cats can also be noxious through their hair and through the look of their eyes. Their spirit is infected with a destructive venom. I know some people, he says, who were so fond of cats that never went to sleep without them and for this reason exposed themselves longer to the effect of their spirit and fell into disease and marasmus that prompted their death. Not long ago a whole monastery perished because of a great number of cats who lived with the monks. As for the harm caused by the look of their eyes, there are some people who are caught with fear upon seeing or hearing them, and he had seen such persons in Gorizia in Germany (now Italy). In the wintertime, when one of them came into a house with us, the woman who was aware of his peculiarity hid a kitten in a chest. But, although he could not see or hear the kitten, after some time when he inhaled the air infected with the cat's breath he began to sweat exclaiming that somewhere in the house there must be a cat (Mattioli 1558: 742).

Laurence Bobis (1997: 724) opines that the medicine of the Middle Ages did not generally regard the cat as a venomous animal, with some notable exceptions like Hildegard of Bingen, Avenzoar, and Maimonides, but this attitude became more common in the Renaissance. I think it difficult to prove that the Renaissance medicine was more averse to the cat. It is true that Mattioli's work exerted a great influence and was abundantly cited on the subject by Ambroise Paré (1841: 333-4, in the "Traite des venins") and Eustachio Rudio (Rudio 1610: 116-117, lib. IV, cap. 8 "De cerebro felis"), to name just a few. But this impact could hardly have been greater than that of Maimonides and Avenzoar in their times. It would be safer to say that the idea of the cat's nocuity as a species has been attested since Hildegard of Bingen and revived and reinforced by Mattioli.

On the contrary, the cat's brain was unequivocally considered strongly poisonous throughout the Middle Ages and afterwards till at least the 17th cent. It was also particularly mentioned by Hildegard of Bingen (see above); but more thorough and detailed accounts of its effects and remedies occur in the early 14th cent., and the first name to be referred to is that of Peter of Abano.

Peter of Abano (d. 1316), an influential philosopher, physician and astrologer who taught in Paris and Padua, commonly mentioned afterwards as Conciliator after the name of his most popular work, 
in his treatise "De venenis et eorum remediis" (around 1310) says that the cat's brain contains a dangerous poison which turns men $\operatorname{mad}^{5}$. He who gets the cat's brain in a draught will suffer dementia and will be seen as if he performs tricks. ${ }^{6}$ The remedy is sealed earth (terra sigillata); one has to vomit with it two times a month, and to take a confection of diamuscus every day early in the morning. And the bezoar against the poison is grated musk, half a scruple, given in a draught with the white wine ${ }^{7}$.

The cat's brain is also touched upon in passing by Pseudo-Lull, "De conservatione vitae" (1349) ${ }^{8}$, and can be found in the "Problemata de venenis" by Christoforus de Honestis written around $1390^{9}$. Sante Arduino (fl. 1430), the author of a comprehensive treatise on poison composed in the 1420s (cf. Gibbs 2017: 162), adopts a more theoretical approach and remarks that the most famous scholars who wrote on venoms did not mention the cat's brain because it is not a poison in the proper sense ${ }^{10}$. True, it mortifies, that is, it destroys the intellect which distinguishes a man from the beasts, and for this reason he finds it appropriate to consider the cat's brain in his compendium among other poisons. It ruins the intellect and causes madness because of its coldness and dryness and its morbid properties generated by the melancholic humour (Arduino 1562: 250-251).

${ }^{5}$ On the treatise see Sodigné-Costes 1995a. The same can be also read in the chapter 2 of the "De venenis", cf. Peter of Abano 1520: 257, where Peter offers a classification of animal poisons according to the parts of the body; see also Sodigne-Costes 1995b: 108-109.

${ }^{6}$ Peter de Abano 1537: 43: "praestigiare videbitur"; Peter de Abano 1520: 260: "istrigiosus videbitur"; Sante Arduino 1562: 250-251 cites the phrase as "hystriosus videbitur". The common idea seems to be of a man acting as a mime, cf. strigio 'mimarius, scenicus' in GMIL VII, col. 614c.

${ }^{7}$ Collard 2003: 53 remarks that "les produits extravagants rencontrés dans les poudres de sorcellerie tiennent bien peu de place dans la littérature savante. Pietro d'Abano aborde la question de la cervelle de chat chère aux sorcières, mais c'est pour en démentir la nocivité". But I was unable to find in Abano's text neither references to the use of the cat's brain by sorcerers, nor any denial of its hazards.

${ }^{8}$ Pseudo-Lull 1616: 64. On the work and other treatises attributed to, but certainly having no connection with Lull, see Patai 1988: 16.

${ }^{9}$ See HMES 1934: 540.

${ }^{10}$ I could not find out which definition of poison could stand behind this rejection. It does not seem to have to do with the theoretical debates on "specific form" since Arduino offers a standard humoral explanation of its action. 
Antonio Guaineri (d. around 1455), a renowned Italian physician, Professor of medicine at Pavia and a doctor at the court of the Duchy of Savoy (cf. HMES 1934: IV, 215ff.; Jacquart 1990), in his treatise "De venenis" composed before 1440 describes the effect of the poison which causes vertigos and madness, and adds "letitia Galieni" to the remedies offered by Peter of Abano (Guaineri 1508: $118 v$ ). Eustachio Rudio (d. 1612) addresses the question why it is the cat's brain, and not its flesh, that causes madness, and answers that the brain has a more destructive power than the rest of the body, as can be seen e.g. in the viper whose head is the storage of poison. The brains of a cat and of a man have natural similarity, and hence the poison in the cat's brain reaches the head and gets absorbed more easily. Furthermore, of all the other parts of the cat, the brain is especially humid and therefore more quickly accepts "the seeds of decay" when heated by the human body. Moreover, those who eat other parts of the cat, macerate them in the flowing water for up to three days and then cook and fry them wherefore their venomous power dissolves (Rudio 1610: 116-117 - lib. IV, cap. 8 "De cerebro felis").

The persistence of the belief on the popular niveau is attested, e.g., by its mention in the Conferences of the Bureau d'adresse public discussions of the scientific and other matters arranged by Théophraste Renaudot (Conferences 1656: 578). Its partial English translation was published in 1664:

"The Third said, That besides those causes, the food taken from some parts of Aliments contributes much to hurt the Imagination of Men in such sort, that they account themselves really brutes. Thus a Maid of Breslaw in Silesia having eaten the brain of a Cat, so strongly conceited her self a Cat, that she ran after every Mouse that appear'd before her. A Spaniard having eaten the brain of a Bear, thought himself to be one. Another that had very often drunk Goats milk, fed upon grass like that Animal. Another who had liv'd long upon Swines blood, rowl'd himself in the mire as if he had been truly a Hogg" (Havers 1664: 205) ${ }^{11}$.

\footnotetext{
${ }^{11}$ Some more examples of the popular beliefs and magical use of the cat's brain, including the story of a maid from Breslau, are assembled in HdA I, 902; HdA IV, 78; the cat's brain is also mentioned, for example, by Andreas Glorez (d. 1700), see Priesner 2011: 185.
} 
As for the remedies, almost all later physicians repeat the recommendations by Peter of Abano, the only exception being Antonio Guaineri who adds one more remedy to Peter's list. It is reproduced by Christophorus de Honestis, Sante Arduino, Pietro Andrea Mattioli, and Eustachio Rudio. Some scholars not mentioned above can be referred to, simply to demonstrate the longevity and extent of the scholarly tradition. Thus, the same antidotes against the cat's brain occur in the writings of Pieter van Foreest 1653: 481 who refers to Guaineri, and Jean Prévost (d. 1631) (1641: 318).

These remedies are ${ }^{12}$ :

1) terra sigillata or terra Lemnia, that is, the earth from Lemnos. Its special curative properties were highly esteemed since classical antiquity. The earth was pressed in tablets and stamped with a seal to prove its authenticity (therefore, sigillata). It was regarded mainly as antidote. See Hasluck 1909/1910.

2) The confection (electuary) of diamuscus was widely known from the "Antidotarium" of pseudo-Mesue who describes it as follows: "A sweet confection of musk helping the heartbeat and melancholic ailments, and also those who are sad without reason, and it is useful against the ailments of the brain such as vertigo and epilepsy and acute pains and paralysis and against the ailments of the lungs and laboured breathing. Its composition is as follows: take 2 drams each of crocus, leopard's bane, zedoary, aloeswood, mace; 2,5 drams each of white pearls, burned crude silk, carob, red coral; 2,5 drams each of gall, lemon basil; 1 dram each of white and red behen, spikenard, cloves; 1,5 drams each of ginger, cubeb, long pepper; 1 dram of musk. Grind two parts [of this mixture] with fresh honey four times heavier than the weight of it all and put in a glass vase. The dose is from 1 dram up to 51" (Grabadin, f. 27r).

3) Musk.

However, those were not the only remedies against the trouble. The manuscript BNF NAL 693 considered here offers the following solution:

(f. 149v) Pur home qe est forsene qe ad ceruel de chat ou de espreuer mange, prenge ij ou iij huwans e si l'en les puet torner blancs, fetes les apariller com gelines a manger et tost la maladie passera.

${ }^{12}$ It is interesting that the remedies against snake poison are entirely different, see Walker-Meikle 2014. 
'For a man who is mad who ate the brain of the cat or of the sparrowhawk, take two or three owls and if you manage to turn them white ${ }^{13}$, make them prepared for eating like hens, and the disease will pass at once'.

This manner of handling the illness differs significantly from the recommendations of the learned physicians mentioned above. It is evident that the recipes taken from scholarly antidotaria which were either translated from Arabic or composed in Southern Europe contain many ingredients alien to England and Northern Europe in general. Hardly a couple of about twenty components in the diamuscus electuary could be found on the spot; almost all needed to be imported and must have been quite expensive on this account alone, to say nothing of such components as white pearls. It is also difficult to imagine that all twenty elements could be properly substituted. Terra sigillata, though simpler in composition, was hard to obtain as well, and the price would have also been a considerable obstacle. Finally, musk itself was extremely expensive in the Islamic world too ${ }^{14}$, and it is reasonable to infer that even its adulterants were not easily affordable in the Far West ${ }^{15}$.

The recipe belongs to the series of materials written much more carelessly than the main texts of the manuscript and is very probably a later addition made by one of its later owners, perhaps, around the middle of the 14th century. These materials are often of markedly more lay character in contrast to the learned texts constituting the core of the manuscript. They are very likely private notes of a practising physician who wrote down bits of useful information for personal use. Under these circumstances, taking into consideration the unavailability of the medicine prescribed in the "official" antidotaria, and the character of the notes, it may be concluded that cooking owls as a remedy against madness caused by consuming the cat's brain was part of a lower stratum of medical learning; it offers a glimpse of the usual, perhaps quotidian practice of an AngloNorman medic.

13 "torner blancs", that is, to remove skin after soaking in hot water, see MED s.v. blaunchen (v.), and the examples given there.

${ }_{15}^{14}$ On the prices see King 2017: 259-260.

${ }^{15}$ On adulteration and imitation see ibid., 262-271; some information on a typical monastic medical storage see Jenkins 1976. 


\section{2.}

On fol. 191r of the same manuscript, there is a recipe for erasing letters.

Vt deleas literam abque rasura, cape cbsfxm eiusdem generis animalis, cuius est et carta. Item colofoniam i. picem grecam ad medietatem cbsfi, et distempera cum succo rute et succo cardonis rubei in equali portione, et permitte siccare ad solem, et sic fac ter. Postea inunge literam cum saliua et mitte de puluere isto desuper et dimitte iacere per horam.

'To erase a letter without scraping, take $c b s f x m$ of the same animal species from which the parchment is made. Then colophony or Greek pitch in the middle of $c b s f i$, and moisten it with the juice of rue and the juice of red thistle in equal proportions, and let it dry in the sun, and do so thrice. Then smear the letter with saliva and put this powder upon it and leave it there for one hour'.

The code used here is a simple substitution cipher of the Caesar type or the standard alphabet cipher which replaces a letter of the original message by another letter in the alphabet ${ }^{16}$. According to Suetonius, Caesar used the third letter after the original one as the substitute (D for A, E for B etc.), but his name is nowadays applied to any variety of this procedure. A further simplification is the method allegedly taken advantage of by Augustus who used as the substitute the next following letter (B for A, C for B etc.), cf. Suet. c. $88^{17}$. In the Middle Ages, an even more uncomplicated system prevailed, which only encoded vowels. It is sometimes called "notae sancti Bonifacii”" (Derolez 1951: 9, cf. also Levison 1946: 290-294) due to the fact that its dissemination was attributed to St Boniface in a short treatise "De inventione linguarum ab Hebraea usque ad Theodiscam, et notis antiquis" written allegedly by Rabanus Maurus (1626: 333-334). It actually covers two different sub-types: in the

\footnotetext{
${ }^{16}$ On this type from the perspective of the modern cryptography see Smith 1971: 18, 57-60, Kahn 1973: 77, Bauer 2000: 51; on ciphers in Classical times see Süß 1923, Reinke 1962.

${ }^{17}$ As noted by Sims-Williams 2007: 171, n. 16, the cipher was readily available to the medieval reader from Isidore, Etymologies, I, xxv (ed. W. M. Lindsay, Oxford 1911, vol. 1): Caesar quoque Augustus ad filium, "quoniam" inquit, "innumerabilia accidunt assidue quae scribi alterutro oporteat et esse secreta, habeamus inter nos notas si vis tales ut, cum aliquid notis scribendum erit, pro unaquaque littera scribamus sequentem hoc modo, pro a b pro $\mathrm{b} c$ et deinceps eadem ratione ceteras; pro $\mathrm{z}$ autem littera redeundum erit ad duplex a a" Quidam etiam versis verbis scribunt.
} 
first one, the vowels are substituted with varying number of $\operatorname{dots}^{18}$, and in the second, with the next letter. Thus, cbsfxm and cbsfi correspond to plain-text caseum and casei respectively, that is, to the Acc and Gen of caseus 'cheese'.

Examples of the use of this cipher may be found in Wattenbach 1886: 12-14, and Levison 1946: 290-294. It often occurs in medical and technical notices and recipes, but rather sporadically. The scribes enciphered not texts or phrases, but isolated words, and their choice is anything but transparent. In the manuscript in question it seems to be the only instance of encipherment. The examples provided by Levison and Wattenbach may be supplemented with the evidence from several specialised texts. The Augsburg UB MS Cod. III 2.8 34 (olim Fürstlich Öttingen-Wallerstein'sche Schloßbibliothek in Harburg) written before $1511^{19}$ is especially rich in enciphered words scattered through the recipes on medical, wine-, paint- and metal-making matters, $\mathrm{cf} . \mathrm{mfchhn}=$ machen, prkt $=$ prot, Rpehnnpr $=$ Rephunner, pnkpm $=$ einem, ekn $=$ ein $($ Vermeer 1961a: 113-118 et passim), drfcknis = draconis, trkvfhlgn = tropfelin, Gpkcrfs = Ipocras (Vermeer 1961b: 243-246). The words encoded with the Caesar cipher occur in the late twelfth-century manuscript of the "Mappae clavicula", namely in the earliest known recipe of alcohol, xknk cum iii. qbsuf. tbmkt $=$ vini cum 3 parte salis $^{20}$. Another instance of its use comes from the "Liber illuministarum" a collection of technical recipes written down in the Tegernsee

\footnotetext{
${ }^{18}$ Derolez 1951: 9-10 suggests the link between some varieties of this subtype which denoted $\mathrm{O}$ with two dots and $\mathrm{U}$ with three, with the Ogam alphabet, but the example he chooses to substantiate his point is not altogether convincing since the dots in lfp:rks (leporis) can be explained otherwise as substitution for "p" which would have stood here according to the next-letter system (lfpprks), in order to avoid doubling of the letter P in two different "meanings". Laubmann 1878: 74, provides a colophon from a 9th century manuscript which at least in some cases clearly uses dots to point out such doubling - here, however, as an additional element, cf. $\Lambda \mathrm{B} \cdot \mathrm{BPR}=$ labor; $\mathrm{HB}: \mathrm{BFT}=$ habet. As for the Ogam, it is interesting that it could have been used to encipher the Latin words in the manner identical with the Caesar cipher if Sims-Williams 2007: 171-172 is right in supposing that the Ogam MEGFDLU could represent "me fecit".

${ }^{19}$ On the MS see Schneider 1988: 687.

${ }^{20}$ The Phillipps-Corning Manuscript, Corning Museum of Glass, MS 5, fol. $45 \mathrm{v}$, available at https://www.cmog.org/library/manuscript-mappaeclavicula cf. also translation in Smith Hawthorne 1974: 59.
} 
Abbey about 1500 (= BSB Cgm 821), cf. dbqkskatr = capitibus, ckeipog $=$ bidhopf (Liber illuministarum: 444).

Thus, cryptography is used by the scribe of the notice just as it is applied in other medical and technical collections - quite accidentally. One may wonder if it was a tool demonstrating the scribe's sophistication and profound knowledge of his field, but it is equally conceivable that he copied the recipe that already contained the enciphered words. This suggestion, in turn, raises the question of how such words could have been interpreted by transmitters. It is known that these collections were at least sometimes transmitted by scribes who were obviously not skilled in the crafts they were writing about (cf. Wallert 1995: 38) or not accustomed to writing at all as one of the scribes himself informs (cf. Merrifield 1849: 291).

There are not so many recipes for erasing letters edited so far (see Checklist in Clarke 2001, Nos. 1880, 1900, 2470, 2790, $3050)^{21}$, and none of them come from a manuscript dated earlier than ours. Four of them come from "Experimenta de coloribus" written down along with other collections of recipes by Jehan le Begue in 1431 (MS BNF lat. 6741) and published by Mary Merrifield (1849, 47-111, Nos. 2, 21, 27, 34). These are undoubtedly based on an older tradition since it is known that Jehan le Begue used the materials collected by his predecessor Jehan Alcherius who had learned much during his travels in Italy. However, none of them have ingredients in common with the formula from the Anglo-Norman manuscript. They prescribe producing a "water" by distilling nitre and Roman vitriol (2), or making a paste from the ground roche alum and orange juice (34) or using the latter alone (27). Another, more elaborate recommendation is to take a hare's thigh ${ }^{22}$, to skin and to salt it, then to dry it over the smoke and

${ }^{21}$ Clarke not always mentions presence of the recipes for erasing letters in the MSS I am referring to. On the other hand, his mentioning of a recipe of this type in the MS Florence, Biblioteca Riccardiana 1243 (No. 980) may be misleading since his source Saxl 1954: 47, in fact, connects it not to the erasing recipe, but to the recipe for removing oil. See also Trier, Stadtbibliothek, Hs 1028/1959 $8^{\circ}$, f. 3r (year1490) and Oxford, Corpus Christi College, MS 125, f. 78 (14th-15th cent.), both with the rubric "ad delendum litteras/litteram".

22 "Accipe cossam leporis, et decoria ipsam." Merrifield 1849: 56 gives a translation "take a hare's skin and dress it" which seems to be inaccurate since cossa here most probably means coxa 'thigh', see GIML, II, col. 593a, and this lends sense to the verb decorio. 
to pulverize (21). The powder will erase letters without damaging the paper.

Arie Wallert (1995) provides English translation of two recipes from the MS Roma, Biblioteca Casanatense, Ms 1793 (year 1422). The first one (No. 18) advises to erase letters with a sponge moistened with the distilled mixture of saltpetre and vitriol (that is, aqua fortis, nitric acid, cf. recipe No. 2 of "Experimenta de coloribus" above) ${ }^{23}$. The second one (No. 42) resembles the recipe No. 27 of the "Experimenta de coloribus" as it suggests using the juice of a lemon or of an orange alone.

Gerolamo Cardano 1558: 600 advocates the use of the powder made of "fig milk", that is, the sap of the fig-tree, and white lead which is to be put on the slightly moistened letters in a parchment to erase them. Curiously, he presents this method in a chapter describing various types of cryptography.

The closest analogy to our recipe is attested in the MS British Library, Sloane 1313 (15th cent.), f. 125r, edited by Wright and Halliwell 1845: 108-109:

To done away what is y-wreten in velyn or parchement without any pomyce. Take the juyst of rewe and of nettyl, in Marche, in Averel, or in May, and medyl hit with chese, mylke of a kow, or of shepe, put therto unqueynt lym, medle hem wel togedur, and make therof a lofe, and drye hit at the sonne, and make therof powdur. When thou wolt do awey the lettre, wete a pensel with spotil or with watur, and moist therwith the lettres that thou wolt do awey, and then cast the powder therupon, and with thi nail thou maist done awey the lettres that hit schal nothyng been a-sene, without any apeyrement. This medecyn, y-made with chese or mylke of a kow, is good for velym; and, of a sepe, good for parchement.

Here we find also cheese (with milk) which is to be mixed with the juice of rue; moreover, the last phrase advising to use the cow cheese (or milk) for vellum and the sheep cheese for parchment instantly reminds us of the curious prescription to "take cheese of the same animal species from which the parchment is made". There are, however, substantial differences. The English recipe places the juice of nettle instead of the juice of red thistle, adds unquenched lime, and, most importantly, does not mention colophony.

\footnotetext{
${ }^{23}$ Wallert 1995: 46, n. 18 remarks that this is similar to the recipes from two other collections preserved in Siena Biblioteca Comunale, MS I.II.19, and MS L.XI.41.
} 
Colophony occurs in a much more later German print "Artliche künste" issued in 1531 and many times reprinted and reworked since then (see Eamon 1984: 119-120). Here appears the recipe for lettererasing which also introduces colophony as one of the two main ingredients, but recommends fresh horse dung instead of cheese as the second one. The horse dung occurs in other recipes, e.g., for making azure and blue colours (Liber illuministarum: 78 and 80, 256), as a conserving and warming means.

Schrifft auff pergamen aus zu leschen

Nim Colofoniam das ist Griechisch hartz zerstos klein vnd strawe es auff die schrifft netze denn ein tuch vnd legs drauff darnach auff das tuch frischen pferds koth oben drauff leg denn ein schlechten zigel vnd las es ym winter ein nacht stehen ym Sommer aber vom morgen an bis es neune schlecht (Artliche künste 1531: xi).

'To erase the writing on the parchment

Take colophony, that is, Greek pitch, grind it very small and scatter it on the writing, then moisten a cloth and lay it over, then put fresh horse dung above, lay a bad brick upon it and let it stay one night in the winter, but in the summer from morning till it chimes nine'.

Thus, I was not able to detect exact correspondences to this recipe, but the partial analogies come from the later hand-written and printed sources. One of them, characteristically mentioning cheese, is preserved in a manuscript also written in Britain, which may point to a local tradition. The second one attesting to the use of colophony is much more remote geographically and temporally, but suggests that this practice also has a long history. Both recipes considered above testify to the broad interests of the possessor(s) who added these notes and to the variety of sources he (they) used. Furthermore, they are very early examples - in the case of the second recipe, perhaps, the earliest edited so far - of their types. Particularly interesting are details that distinguish them from other instances - a very special antidote made of owls against the cat's brain in the first case, and a specific combination of colophony and cheese with the juice of rue and the juice of red thistle, along with the use of cryptography, in the latter. These peculiarities as well as the whole body of the notes added to the manuscript give insight into the living tradition of popular knowledge available to the practicing physician on the Welsh border of the 14th century. It is to be expected that publication of recipe collections still unedited will 
provide additional material for comparison which will help establish a more comprehensive context and perhaps find more exact parallels.

\section{Bibliographie}

Ackermann, H. 1986: Moses Maimonides (1135-1204): Ärztliche Tätigkeit und medizinische Schriften. Sudhoffs Archiv 70(1), 44-63.

Arduino, S. 1562: Santis Ardoyni Pisavrensis medici et philosophi praestantissimi opus De venenis [...]. Basileae.

Artliche künste 1531: Artliche künste mancherley weise Dinten und aller hand Farben zubereiten, Auch Gold und Silber sampt allen Metallen aus der Fedder zu schreiben (...) [Erffurdt : Sachss, 1531] [VD16 A 3857].

Avenzoar. 1490: Abumeron. Auenzohar. Uenetijs [BSB-Ink A-950 - GW 3103].

Bacci, A. 1586: De venenis, et antidotis prolegomena, seu communia pracepta ad humanam vitam tuendam saluberrima... Andrea Baccio Elpidiano Medico. Romae.

Bar-Sela, A., Hoff, H. E., Faris. E. 1964: Moses Maimonides' Two Treatises on the Regimen of Health: Fì Tadbīr al-Șiḥhah and Maqālah fi Bayān Ba'ḍ al-A'rāḍ wa-al-Jawāb 'anhā. Transactions of the American Philosophical Society 54(4), 3-50.

Bauer, F.L. 2000: Entzifferte Geheimnisse: Methoden und Maximen der Kryptologie, Dritte, überarbeitete und erweiterte Auflage. Berlin New York.

Bobis, L. 1997: Des usages du chat dans la médecine de la fin de l'Antiquité et du Moyen-Âge. In: Mornet, E., Morenzoni, F., eds. Milieux naturels, espaces sociaux: études offertes à Robert Delort. Paris, 717-728.

Bobis, L. 2000: Une histoire du chat: De l'Antiquité à nos jours. Paris.

Cardano, G. 1558: Hieronymi Cardani Mediolanensis, medici, De rerum varietate libri xvii. Avinione.

Chandelier, J. 2009: Théorie et définition des poisons à la fin du Moyen Âge. Cahiers de Recherches Médiévales 17, 23-38.

Clarke, M. 2001: The Art of All Colours: Mediaeval Recipe Books for Painters and Illuminators. London.

Collard, F. 2003: Veneficiis vel maleficiis. Réflexions sur les relations entre le crime de poison et la sorcellerie dans l'Occident medieval. Le Moyen Âge 109, 9-57.

Conferences 1656: Recueil général des questions traitées es conférences du bureau d'adresse, sur toutes sortes de matieres, par les plus beaux esprits de ce temps. Paris.

Derolez, R. 1951: Ogam, "Egyptian", "African" and "Gothic" alphabets: Some remarks in connection with Codex Bernensis 207. Scriptorium 5(1), 3-19.

Eamon, W. 1984: Arcana Disclosed: The Advent of Printing, the Books of Secrets Tradition and the Development of Experimental Science in the Sixteenth Century. History of Science 22(2), 111-150.

van Foreest, P. 1653: Observationum et curationum medicinalium, Tomus III. Rothomagi. 
Gessner, C. 1620: Conr. Gesneri (...) Historiae animalium liber primus De quadrupedibus viviparis. Francofurti.

Gibbs, F. 2017: Medical Literature on Poison, c. 1300-1600. In: Wexler, P., ed. Toxicology in the Middle Ages and Renaissance. London, 159166.

GMIL: du Cange, et al. Glossarium mediae et infimae latinitatis, éd. augm. Niort 1883-1887.

Grabadin: Johannis Mesue Grabadin Incipit Quod est aggregacio et antidotarium electuariorum et confectionum. In: Antidotarium Nicolai (Blatt 3r-24v) und Grabadin (Blatt 26r-68r). Straßburg ca. 1478 [GW M26754].

Guaineri, A. 1508: Practica Antonii Guainerii Papiensis doctoris clarissimi et omnia opera. Venetiis.

Hasluck, F.W. 1909/10: Terra Lemnia. The Annual of the British School at Athens 16, 220-231.

Havers, G. 1664: A general collection of discourses of the virtuosi of France, upon questions of all sorts of philosophy, and other natural knowledg made in the assembly of the Beaux Esprits at Paris, by the most ingenious persons of that nation / render'd into English by G. Havers, Gent. London.

HdA: Handwörterbuch des deutschen Aberglaubens, 10 Bd., Berlin 19271942.

Hildegard von Bingen, 2010: Physica: Liber subtilitatum diversarum naturarum creaturarum, hrsg. v. Hildebrandt, R., Gloning, T., Bd. 1-2, Berlin; New York.

HMES: Thorndike, L. A History of Magic and Experimental Science, 8 vols., New York, 1923-1958.

Ivanov, S., Falileyev A. 2017: Bibliothèque nationale de France NAL 693 and some episodes in the history of Monmouth in the fourteenth century. The Welsh History Review 28(3), 457-469.

Jacquart, D. 1990: Theory, Everyday Practice, and Three Fifteenth-Century Physicians. Osiris 6, 140-160.

Jenkins, M. 1976: Medicines and Spices, with Special Reference to Medieval Monastic Accounts. Garden History 4(3), 47-49.

Kahn, D. 1973: The Codebreakers: The Comprehensive History of Secret Communication from Ancient Times to the Internet, revised ed. New York.

King, A.H. 2017: Scent from the Garden of Paradise: Musk and the Medieval Islamic World. Leyden - Boston (Islamic History and Civilization: Studies and Text 140).

Laubmann, G. 1878: Mittheilungen aus Würzburger Handschriften, Sitzungsberichte Bayer. Akad. der Wiss. Phil.-hist. Klasse, II, 71-96.

Levison, W. 1946: England and the Continent in the Eighth Century. Oxford.

Liber illuministarum: Bartl, A., Krekel, C., Lautenschlager, M., Oltrogge, D. Der „Liber illuministarum“ aus Kloster Tegernsee: Edition, Übersetzung und Kommentar der kunsttechnologischen Rezepte, Stuttgart 2005.

Maimonides 1518: Tractatus Rabbi Moysi de regimine sanitatis ad Soldanum regem. Augsburg. 
Mattioli, P.A. 1558: Petri Andreae Matthioli Senensis Commentarii Secvndo Avcti, In Libros Sex Pedacii Dioscoridis Anazarbei de medica materia. Venetiis.

MED: Middle English Dictionary, available online at https://quod.lib.umich.edu/m/med/

Merrifield, M.P. 1849: Original Treatises, dating from the XIIth to XVIIIth centuries, on the Arts of Painting, Vol. 1. London.

Nicoud, M. 2007: Les régimes de santé au Moyen Âge. Naissance et diffusion d'une écriture médicale en Italie et en France (XIIIe-XVe siècle), 2 vol., Roma (Bibliothèque des Écoles françaises d'Athènes et de Rome. Première série 333).

Paré, A. 1841: Oeuvres completes, III. Paris.

Patai, R. 1988: Raymund de Tarrega - Marrano, Heretic, Alchemist. Ambix $35,14-30$.

Peter of Abano 1520: Conciliator differentiarum philosophorum et medicorum in primis doctoris in omni disciplinarum genere eminentissimi Petri de Abano Patavini. Luceantonii de Giunta.

Peter of Abano 1537: Clarissimi celeberrimique olim philosophi \& medici Petri de Abano De venenis atque eorundem commodis remediis Liber plane aureus, per Joannem Dryandrum medicum, pristino suo nitori restitutus. Marpurgi.

Prévost, J. 1641: Ioannis Praevotii (...) Medicina pauperum ac ejusdem De venenis (...). Frankfurt.

Priesner, C. 2011: „Der zu vielen Wissenschaften anweisende curiöse Künstler". Alchemie, Volksmagie und Volksmedizin in barocken Hausbüchern. Sudhoffs Archiv 95(2), 170-208.

Pseudo-Lull 1616: Raymvndi Lvllii Tractatvs Brevis Et Eruditus De Conservatione Vitae, item Liber secretorum seu Quintae essentiae. Strassburg.

Rabanus Maurus 1626: Magnentii Hrabani Mauri ... opera, quae reperiri potuerunt, omnia: in sex tomos distincta, Tomus 6. Köln.

Reinke, E.C. 1962: Classical Cryptography. The Classical Journal 58(3), $113-121$.

Rudio, E. 1610: Eustachii Rudii De morbis occultis, et venenatis libri quinque. Venetiis.

Saxl, H. 1954: An Investigation of the Qualities, the Methods of Manufacture and the Preservation of Historic Parchment and Vellum with a View to Identifying the Animal Species Used, M.Sc. thesis. Leeds.

Schneider, K. 1988: Deutsche mittelalterliche Handschriften der Universitätsbibliothek Augsburg. Die Signaturengruppen Cod. I.3 und Cod. III.1. Wiesbaden (Die Handschriften der Universitätsbibliothek Augsburg II,1).

Sims-Williams, P. 2007: Byrhtferth's Ogam Signature. In: Sims-Williams, P. Studies on Celtic Languages before the Year 1000, Aberystwyth 2007, 169-177. First published in: Jones, T., and Fryde, E. B. (eds.). Ysgrifau a cherddi cyflwynedig i Daniel Huws: Essays and poems presented to Daniel Huws. Aberystwyth, 283-291.

Smith, L.D. 1971: Cryptography: The Science of Secret Writing. New York. 
Smith, C. S. S., Hawthorne, J. G. 1974: Mappae Clavicula: A Little Key to the World of Medieval Techniques. Transactions of the American Philosophical Society 64(4), 1-128.

Sodigné-Costes, G. 1995a: Un traité de toxicologie médiévale: le Liber de venenis de Pietro d'Abano (traduction française du début du $\mathrm{XV}^{\mathrm{e}}$ siècle). Revue d'histoire de la pharmacie 42 (305), 125-136.

Sodigné-Costes, G. 1995b: Les animaux venimeux dans le Livre des venins de Pietro d'Abano. Reinardus 8, 101-114.

Süß, W. 1923: Ueber antike Geheimschreibemethoden und ihr Nachleben. Philologus 78 (N.F. 32), 142-175.

Touwaide, A. 1994: Galien et la toxicology. In: Aufstieg und Niedergang der Römischen Welt, Vol. 37:2, ed. W. Haase, Berlin-New York, 1887-1986.

Vermeer, H. J. 1961a: Technisch-naturwissenschaftliche Rezepte aus einer Harburger Handschrift. Sudhoffs Archiv für Geschichte der Medizin und der Naturwissenschaften 45(2), 110-126.

Vermeer, H. J. 1961b: Eine altdeutsche Sammlung medizinischer Rezepte in Geheimschrift. Sudhoffs Archiv für Geschichte der Medizin und der Naturwissenschaften 45(3), 235-246.

Walker-Meikle, K. 2014: Toxicology and Treatment: Medical Authorities and Snake-Bite in the Middle Ages. Korot 22, 85-104.

Wallert, A. 1995: Libro Secondo de Diversi Colori e Sise da Mettere a Oro: A Fifteenth-Century Technical Treatise on Manuscript Illumination. In: Wallert, A., Hermens, E., and Peek, M. (eds.) Historical Painting Techniques, Materials, and Studio Practice: preprints of a symposium [held at] University of Leiden, the Netherlands, 26-29 June 1995. Malibu, 38-47.

Wattenbach, W. 1886: Anleitung zur lateinischen Palaeographie. 4. verbesserte Aufl. Leipzig.

Wright, T., Halliwell, J.O. 1845: Reliquiae antiquae: Scraps from Ancient Manuscripts, illustrating chiefly Early English Literature and the English Language. Vol. 1. London.

Zacuto 1637: Zacuti Lusitani, Medici et Philosophi praestantissimi, Praxis medica admiranda [...], Lugduni.

Summary: The paper considers two items from the Anglo-Norman collection of technical and medical recipes. The first one reveals an interesting method of healing the illness caused by consumption of the cat's brain by means of cooking owls. The second one, which provides a description of a mixture for erasing letters from parchment, contains a curious example of cryptography. They are put into context with other texts and recipes of this type in order to evaluate the differences which may point to a local tradition. Both recipes are presumably latter additions made by an owner who was a practising physician, and thus offer an insight into the popular knowledge of the 14th century Britain.

Keywords: medieval medicine, recipes, manuscript tradition, cryptography. 